Ethiopian Journal of Environmental Studies \& Management 7(3): 327 - 338, 2014.

ISSN:1998-0507

doi: http://dx.doi.org/10.4314/ejesm.v7i3.13

Submitted: March 10, 2014

Accepted: May 14, 2014

\title{
ECOTOURISM RESOURCES OF UNIVERSITY OF UYO, NIGERIA: THE ARBORETUM AND RAVINE DESTINATIONS IN PERSPECTIVE
}

\author{
*IJEOMAH, H.M., ${ }^{1}$ OKOLI, C.I.C. ${ }^{2}$ AND IYAH, E.I. ${ }^{3}$ \\ ${ }^{1}$ Department of Forestry and Wildlife Management, Faculty of Agriculture, University of Port Harcourt, \\ P.M.B.5323 Port Harcourt, Rivers State, Nigeria \\ ${ }^{2}$ Department of Hospitality and Tourism Management, Imo State University, P.M.B.2000 Owerri, Imo \\ State \\ ${ }^{3}$ Department of Forestry and Wildlife, University of Uyo, P.M.B.1017, Uyo, Akwalbom State, Nigeria
}

\begin{abstract}
Ecotourism potentials of the University of Uyo Arboretum and Ravine were investigated to determine respondents' awareness of the ecodestinations, willingness to visit the sites, perceptions of the sites as ecodestinations, and factors that can enhance visitation to the destinations. Data for the study were collected through a set of structured questionnaire and personal interviews. A total of 180 respondents were sampled. Data obtained were analyzed using descriptive statistics and Chi-square. Results showed that $81.6 \%$ and $85.5 \%$ of the respondents were aware of the Ravine and Arboretum respectively. Many respondents viewed the ravine as a wildlife habitat (41.1\%) and a place for illicit meetings (26.1\%). Only few respondents (7.7\%) perceived the Ravine as a recreation centre. About $38.3 \%$ of the respondents regarded the Arboretum as a recreation centre while $51.5 \%$ viewed it as an educational facility. Though most respondents (67.2\%) have visited the Ravine for different reasons greater percentage (75.0\%) of both the males and females interviewed were neither willing to repeat visit nor encourage relations to visit the site. In the case of the Arboretum, $75.0 \%$ of respondents have visited for study (36.6\%), relaxation (13.3\%) and site seeing (10.0\%). More respondents (47.7\%) are willing to visit the Arboretum than the Ravine. Chi square analyses to test for association between respondents perception of ecodestinations and gender were not significant $(p>0.05)$ for both destinations. Tree canopies and topography of the Ravine (41.1\%; 31.1\%) and Arboretum (58.3\%; 32.7\%) were rated major attractions in the destinations. Among the species that formed the canopies for the Ravine are Bambusa vulgaris, Cassia seamia, Elaeis guineensis and Melicia excelsa while Gmelina arborea, Nauclea diderichii and Cassia seamea are the dominant species in the Arboretum. Both the Ravine and Arboretum have potentials for ecotourism but are not managed to attract tourists.
\end{abstract}

Key Words: Biodiversity utilisation, Ecotourism destination, Arboretum, Ravine, University of Uyo, Recreation

\section{Introduction}

Destinations are places that provide uniqueness of experience and product (USAID, 2005). Human beings would always desire to recreate as a strategy to overcome accummulated physical and psychological stress caused by daily activities in work places or pursuits. Recreation is one of the reasons people embark on tours as visitation to destinations offer unique experiences and aid tourists to keep fit. The value tourists place on visits to a destination depends on satisfaction of their individual expectations. The value of a destination does not therefore, except in few cases of mass tourism, universally depend on the largeness of number of tourists found therein because some tourists prefer sites (such as mountain tops, wilderness areas, springs, waterfalls, caves or valleys) that are devoid of persons. In such cases interaction with nature and personal enhancement or knowledge acquired about nature is more valued.Visitors to such destinations may seriously be craving to experience nature in action or 'the naturality of nature' and 'the rurality of rurals' (Ijeomah and Aiyeloja 2010; Ijeomah and Herbert, 2012). Those who embark on such tours are referred to as ecotourists while the concept of embarking on such tours is called ecotourism. The concept, ecotourism dates back to the 1960s when ecologists and environmentalists became

*Corresponding Author: Ijeomah, H.M.

Email: henryijeomah@yahoo.com 
concerned over the inappropriate use of natural resources. The preservation of biodiversity was threatened in favour of economic interest and the exploitation of natural resources. In 1965 Hetzer, the Mexican ecologist introduced the term 'ecotourism' and identified four guiding values for the operation of this form of tourism. According to Hetzer (1965) ecotourism should have (1) minimum environmental impact, (2) minimum impact on - and maximum respect for -host cultures, (3) maximum economic benefits to the host communities, and (4) maximum recreational satisfaction to participating tourists. Ceballos-Lascurain (1987) gave an encompassing and working definition of ecological tourism or ecotourism as that tourism which involves travelling to relatively undisturbed or uncontaminated natural areas with the specific objective of studying, admiring and enjoying the scenery and its wild plants and animals and any existing cultural manifestations (both past and present) found in these areas. Put in another way, ecotourism involves traveling to natural areas that conserve the environment and sustain the wellbeing of local people (Blangy and Wood, 1993), mainly for uniqueness of experience.

The main ecotourism attraction in Africa is wildlife (Eltingham, 1984) and the major scene of wildlife based tourism is park, which is always located in rural areas. The diverse attractions in wildlife parks include combination of abundance, rare and endangered species of wild animals, contemporary cultural manifestation of park host communities in a natural context (Drum and Moore, 2002), unusual micro climatic conditions experienced through nature trails; shades provided by different canopies of age - old trees; springs of different colour, temperature, velocity of flow; and water falls that are in different forms and layers. Negi (1990) cited by Ijeomah and Aiyeloja (2010) enumerated the attraction in rural areas where parks are always found as enjoyment of rural sports like hunting and fishing, ethnic attractions like folk life, custom, food, drinks and historical attractions like castle, churches, temples and interactions with natural environment. Apart from wild animals many other attractions exist in Africa. In fact there is no area without attractive virtues due to differences in human perception as influenced by diversity of experience and geographical background
(Ijeomah et al., 2005). However, within similar destination and when assessed by same persons, some attractive virtues are rated higher and more valueable than others because of their uniqueness in terms of perculiarity and number of persons they could naturally arouse their interest (Ijeomah et al., 2005), even though there might be restriction of access to some potential visitors (in the case of ecotourism) due to environmental conservation reasons. People can travel to other regions of the world to view neglected resources in their (own) locality that have become properly harnessed, packaged and publicised in that region. The shrine of Imam Reza in Iran attracts over 12 million visitors each year (Van der Wagen, 2005) whereas the advent of western religion has led to continuous destruction of many shrines (including touristic ones) in eastern part of Nigeria (Ijeomah et al., 2007; Ijeomah et al., 2011a).

The tourism resources of Akwa Ibom State are yet to be harnessed to benefit host communities. The level of awareness of these resources in their respective ecotourism destinations in many areas of the State, perceptions about them as tourists' attractions, and the willingness of people to visit them (including the University of Uyo) are yet to be known. This situation is aggravated by the fact that the ability of the sites to attract even local visitors has not been assessed. Universities are embodiments of resources. As macro destinations universities host various events, and are among the major attractions in many areas. These inherent attractive virtues embedded in them should therefore not be left unutilised. None utilization of Pai River game reserve of Plateau State for ecotourism due to neglects by the management institution has resulted in encroachment by Fulani herdsmen, who remain resident in the ecotourism site (Ijeomah, 2012a). Universities are unique for their micro destinations with varied attractions. They are mini worlds or micro globes created by man and therefore have diverse attractions, which ranges from environmental, cultural, architectural and historical backgrounds among others. However, many of these attractions are unknown to none members (and some members) of the university community. Even those aware of these resources rarely utilise them as they are not properly 
packaged. Consequent upon this, the ecotourism potentials in these ecodestinations, therefore, are hardly planned for, or properly tapped by the university authorities in Nigeria.Attractive natural water course at the entrance of Bingham Private University in Karu, Nasarawa State, that flows through varied rocky terrain could be packaged to serve as an ecodestination especially when crocodile and species of fish are reared therein, but these resources are yet to be utilised. The passage of Otammiri river through the Federal University of Technology Owerri in Ihiagwa community of Owerri West Local Government (to Nekede, Obinze and many other communities before finally joining the Atlantic ocean via Ozuzu in Etche, Rivers State) has created diverse virtues for ecotourism in the university, which has not been utilised.Many parts of Africa have remained undeveloped partly due to the inability to effectively harness and maximize the value of their abundant raw materials including the ones in universities. If there is any area in Africa and Nigeria in particular, where valuable natural resources should be fully identified, well packaged, properly harnessed and effectively marketed to benefit the populace, a university, especially the University of Uyo in the Niger Delta ( - a very rich region but known for struggle for survival due to oil pollution)(Ijeomah et al., 2011b) is the one.

\section{Objectives of the Study}

The objectives of this paper are to: asssess respondents' awareness of these eco-destinations, investigate the potential willingness to visit the eco-destinations, assess peoples' perception of the sites as ecotourism destination, determine the factors that can enhance people's visitation to these eco-destinations and know the dominant species of plant found in these eco-destinations.

\section{Materials and Method Study Area}

The study was conducted in the department of Forestry and Wildlife Arboretum and the Ravine both in the University of Uyo, Akwa Ibom State. The Arboretum lies between latitudes $4^{\circ} 35^{1}$ and $5^{0} 35^{1} \mathrm{~N}$ and longitudes $7^{0} 35^{1}$ and $8^{\circ} 25^{1} \mathrm{E}$. It was allocated to the department of Forestry and Wildlife by the faculty of Agriculture of University of Uyo farm committee in 1994 for arboretum and departmental nursery.
It covers an area of 1.08ha. The area was organized into compartment and assigned to cover different forestry operations: Gmelina woodlot, bush fallow, Cassia species woodlot, Agroforestry.

In 1995 planting season, Gmelina and Cassia species woodlots were established along with all the trees marking the nursery boundary. Indigenous tree species planted in the Arboretum include: Lovoa weineana, Mammea africana, Pterocarpus species, Mimusops djave, Entandrophragma species and Nauclea diderrichii. The area marked out for bush fallow was planted up in 1996 with Anthonatha macrophylla and Dactyladenia baterii and was allowed to grow undisturbed into forest. About hundred metres from the Department of Forestry and Wildlife of the university of Uyo to the entrance of the Aboretum is planted with two rows of Teak (Tectona grandis) along the walkway, with none of the trees being below 20 metres in height. This created a natural canopy which shaded the non vegetated walkway.

The University of Uyo Ravine is in the plain of south east of the University of Uyo, which is located on latitude $04^{\circ} 52^{\prime} \mathrm{N}$ and longitude $07^{\circ}$ $47^{\prime} \mathrm{E}$. The ravine is a product of heavy and uncontrolled deforestation. The loss of vegetation cover through deforestation leads to the extension of the ravine.The ravine is a steep sloped and receives much of drain water from the adjoining village. There are 8 villages that the ravine spread across within Uyo communities: Ibaoku,

Nduetong Oku, Afaha Oku, Ikot Akpan Oku, Ewet Offot, Eniong Offot, Anua Offot and Ekpri Nsukara. The main campus of University of Uyo also adjoins the ravine on one side. Data Collection

Data used for the study were collected through administration of structured questionnaire, and in-depth interviews with members of the University of Uyo community and the adjoining communities who had stayed a minimum of five years in the environment and therefore are quite knowledgeable about the Ravine and Arboretum. A set of structured questionnaire was administered to respondents from each class of faculty in the University of Uyo in such a way that fifty percent of females and fifty percent of males were interviewed. The set of Questionnaire was administered to only 
those who had spent a minimum of two years in Uyo metropolis.

The ecodestinations were visited with a knowledgeable person on plant identification. Plant species with up to ten individuals that are at least $3 \mathrm{~m}$ in height or emergent were observed, identified and recorded as a dominant species. Emergent plant species were as well recorded for being among the species that formed the canopies.

\section{Sampling Design}

The faculties in the University of Uyo and the adjoining communities to the ravine and arboretum were listed and stratified into four strata based on population. The strata were: big faculty, medium faculty, small faculty and extended faculties in accordance with Ijeomah et al. (2011c). One faculty was randomly selected from each of the strata while the Ekpanya and Eka streets were sampled as extended faculties, being the closest areas to the ravine and arboretum respectively. A set of fifty and forty respondents were sampled in big faculties and medium faculties respectively, while 30 respondents were sampled in the selected small faculties, and Eka and Ekpanya street each, which are extended faculties. In all, 180 respondents were sampled in such a way that the number of males and females were equal.

\section{Data Analysis}

Data collected were analysed using descriptive statistics in the form of percentages and frequency of counts while Chi square was used to test for association between perceptions of the ravine and arboretum and gender of respondents.

\section{Results \\ Respondents' Awareness of Ecodestinations}

Table1 shows that majority $(81.6 \%)$ of the respondents are aware of the Ravine, while only $18.33 \%$ of respondents (male and female) are unaware of the ravine. Table 2 reveals that $85.5 \%$ of the respondents are aware of the Arboretum, while only $14.4 \%$ of the respondents are not aware of the arboretum.

Table 1: Assessment of respondents' awareness of ravine ecodestination

\begin{tabular}{lll}
\hline Awareness assessment & Frequency & Percentage \% \\
\hline Aware & 147 & 81.6 \\
Male & 73 & 40.5 \\
Female & 74 & 41.1 \\
Not aware & & 18.2 \\
Male & 17 & 9.4 \\
Female & 16 & 8.8 \\
\hline
\end{tabular}

Table 2: Assessment of Respondents' Awareness of Forestry Arboretum

\begin{tabular}{lll}
\hline Awareness assessment & Frequency & Percentage \% \\
\hline Aware & 154 & 85.5 \\
Male & 79 & 43.8 \\
Female & 75 & 41.6 \\
Not aware & & \\
Male & 11 & 6.1 \\
Female & 15 & 8.3 \\
\hline
\end{tabular}

\section{Respondents' Perception of Ecodestinations}

Table 3 presents different perceptions of the respondents about the Ravine. Greater percentage of the respondents viewed the ravine as a habitat for wildlife species $(41.1 \%)$ and a meeting place for occult members $(26.1 \%)$.

About $17 \%$ of the female respondents viewed the Ravine as a place where occultism takes place, while lesser percentage of males $(9.4 \%)$ perceived the Ravine as a place for illicit meetings. Contrarily more males (23.3\%) viewed the Ravine as a habitat for wild animals, while lesser percentage of the females $(17.7 \%)$ stated that the Ravine is a habitat for wild animals. Only few respondents $(7.7 \%)$ perceived the ravine as a recreational centre.

\section{Gender Perception of Ecodestination}

Table 4 shows that $38.3 \%$ of the respondents perceived the forestry Arboretum as a recreational centre while $51.5 \%$ (cumulative of 
$15.0 \%, 18.3 \%, 7.7 \%$ and $10.5 \%)$ linked it as a place that is utilized for educational purpose (planting of trees, research, study centre and practical site). Only $4.4 \%$ of the respondents viewed the Arboretum as a place for operation of secret cults.

\section{Respondents' Visitation to the Ravine and Arboretum}

Table 5 shows that $67.2 \%$ of both male and female respondents have visited the ravine, while $32.7 \%$ respondents have not visited the ravine. About $30.7 \%$ of (both male and female) respondents visited the ravine for site seeing of the ecodestination. About $67.21 \%$ of the respondents have observed people visiting the ravine while $32.7 \%$ of respondents have not observed people visiting the ravine

Only $25.0 \%$ of the respondents (both male and female) can encourage people to visit the ravine for relaxation, while $75.0 \%$ of the respondents are neither willing to visit the ravine for recreation nor encourage anybody to visit. The Table also indicated that $40.55 \%$ of the respondents recommend the environment as a relaxation centre, while $59.43 \%$ of the respondents did not recommend the environment as a relaxation centre.
Majority (41.4\%) of the respondents considered tree canopies as the features that can attract tourists to the ravine, $31.1 \%$ of the respondents said that the topography of the area can attract tourist, while $15.0 \%$ of the respondents feel that the ravine can be made more attractive by introducing a zoo therein.

Table 6 indicated that $75.0 \%$ of both male and female have visited the forestry arboretum while $25.0 \%$ of respondent have not visited the destination. Respondent's reasons for visiting the arboretum are: for study (36.6\%), relaxation $(13.3 \%)$, site viewing $(10.0 \%)$ and to urinate $(3.8 \%)$.

\section{Dominant Plant Species in Ecodestinations}

Table 7 shows some dominant plant species in the ravine as Bambusa vulgaris (Indian Bamboo), Cassia seamea (Cassia), Elaeis guineensis (Oil palm), Melicia excelsa (Iroko), Bacteria nitritigana (ant trees) and Musanga cecropioides (Umbrella trees).

Table 8 shows some dominant plant species in the Arboretum as Gmelina arborea, Nauclea diderichii, Cassia seamia, Acacia auricurformis, Mammea africana, Tamarindus indicus, Dactyladenia barterii, Entandrophragma cylinderica and Tectona grandis.

Table 3: Gender Perception of the Ravine

\begin{tabular}{llllllll}
\hline & Occultism & Valley & $\begin{array}{l}\text { Research } \\
\text { Site }\end{array}$ & $\begin{array}{l}\text { Dumping } \\
\text { of refuse }\end{array}$ & $\begin{array}{l}\text { Habit } \\
\text { wildlife }\end{array}$ & $\begin{array}{l}\text { Recreation } \\
\text { centre }\end{array}$ & Total \\
\cline { 2 - 8 } Fale & $17(9.4 \%)$ & $9(5.0)$ & $2(1.1)$ & $13(7.2)$ & $42(23.3 \%)$ & $7(3.8)$ & 90 \\
\hline Total & $30(16.6 \%)$ & $3(1.6)$ & $3(1.6)$ & $15(8.3)$ & $32(17.7 \%)$ & $7(3.8)$ & 90 \\
\hline
\end{tabular}

Chi square analysis to test for association between perception of the ravine and gender was not significant (p>0.05)

* Numbers in parenthesis are percentage values

Table 4: Gender perception of the Arboretum

\begin{tabular}{llllllll}
\hline Gender & Planting of trees & Research & $\begin{array}{l}\text { Study } \\
\text { centre }\end{array}$ & $\begin{array}{l}\text { Recreational } \\
\text { centre }\end{array}$ & Practical site & $\begin{array}{l}\text { Occultism } \\
\text { site }\end{array}$ & Total \\
\hline Male & $11(6.1)$ & $15(8.3)$ & $6(3.3)$ & $33(18.3)$ & $12(6.6)$ & $3(1.6)$ & 90 \\
Female & $16(8.8)$ & $18(10.0)$ & $8(4.4)$ & $36(20.0)$ & $7(3.8)$ & $5(2.7)$ & 90 \\
\hline Total & $27(15.0)^{*}$ & $33(18.3)$ & $14(7.77)$ & $69(38.3)$ & $19(10.5)$ & $8(4.4)$ & 180 \\
\end{tabular}

* Numbers in parenthesis are percentage values Chi square analysis to test for association between perception of the Arboretum and gender of respondents was not significant $(\mathrm{p}>0.05)$. 
Table 5: Assessment of Respondents' Visitation to Ravine Ecodestination

\begin{tabular}{|c|c|c|c|}
\hline Parameter & Variable & Frequency & Percentage $\%$ \\
\hline Visitation to the ravine & Visited & 121 & 67.2 \\
\hline & $\begin{array}{l}\text { Male } \\
\text { Female } \\
\text { Not visited } \\
\text { Male } \\
\text { Female }\end{array}$ & $\begin{array}{l}64 \\
57 \\
90 \\
37 \\
53\end{array}$ & $\begin{array}{l}35.5 \\
31.6 \\
50.0 \\
20.5 \\
29.5\end{array}$ \\
\hline Reasons for Visiting the Ravine & $\begin{array}{l}\text { Viewing of the place } \\
\text { For Research } \\
\text { For study } \\
\text { Dumping of refuse } \\
\text { Urinating } \\
\text { Relaxation } \\
\text { Seed collection }\end{array}$ & $\begin{array}{l}55 \\
10 \\
32 \\
8 \\
2 \\
8 \\
7\end{array}$ & $\begin{array}{l}30.5 \\
\\
5.5 \\
17.7 \\
4.4 \\
1.1 \\
4.4 \\
3.8\end{array}$ \\
\hline $\begin{array}{l}\text { If respondent has observed people } \\
\text { visiting to the ravine }\end{array}$ & Observed & 73 & 40.5 \\
\hline $\begin{array}{l}\text { Can you advice people or relations to } \\
\text { visit the ravine? }\end{array}$ & $\begin{array}{l}\text { male } \\
\text { female } \\
\text { Yes } \\
\text { Male } \\
\text { Female } \\
\text { No } \\
\text { Male } \\
\text { Female }\end{array}$ & $\begin{array}{l}48 \\
25 \\
45.0 \\
21 \\
24 \\
135 \\
69 \\
66\end{array}$ & $\begin{array}{l}26.6 \\
13.8 \\
25.0 \\
11.7 \\
13.3 \\
75.0 \\
38.4 \\
36.6\end{array}$ \\
\hline $\begin{array}{l}\text { If the environment Look good for } \\
\text { relaxation? }\end{array}$ & $\begin{array}{l}\text { Yes } \\
\text { Male } \\
\text { Female } \\
\text { No } \\
\text { Male } \\
\text { Female }\end{array}$ & $\begin{array}{l}73 \\
33 \\
40 \\
107 \\
57 \\
50\end{array}$ & $\begin{array}{l}40.6 \\
18.3 \\
22.2 \\
59.4 \\
31.6 \\
27.2\end{array}$ \\
\hline $\begin{array}{l}\text { Identified major Attraction in the } \\
\text { destination }\end{array}$ & $\begin{array}{l}\text { Tree canopies } \\
\text { None } \\
\text { topography } \\
\text { low temperature }\end{array}$ & $\begin{array}{l}75 \\
22 \\
56 \\
27\end{array}$ & $\begin{array}{l}41.4 \\
12.5 \\
31.1 \\
15.0\end{array}$ \\
\hline
\end{tabular}


Table 6: Assessment of Respondents' Visitation to the Forestry Arboretum

\begin{tabular}{|c|c|c|c|}
\hline Parameter & Variables & Frequency & Percentages $\%$ \\
\hline \multirow[t]{2}{*}{ Visitation to the arboretum } & Visited & 135 & 75.0 \\
\hline & Not visited & 45 & 25.0 \\
\hline \multirow[t]{9}{*}{ Reason for visiting } & Study & 66 & 36.6 \\
\hline & Smoking & 15 & 8.3 \\
\hline & Practical site & 13 & 7.2 \\
\hline & Visitation of the site & 18 & 10.0 \\
\hline & Urinating & 7 & 3.8 \\
\hline & Research & 16 & 8.8 \\
\hline & Relaxation & 24 & 13.3 \\
\hline & No answer & 18 & 10.0 \\
\hline & Seed collection & 3 & 1.6 \\
\hline If respondent has observed peoples & Observed & & \\
\hline \multirow{2}{*}{ visiting to the forestry Arboretum } & & 150 & 83.3 \\
\hline & Not Observed & 30 & 16.6 \\
\hline \multirow{2}{*}{$\begin{array}{l}\text { Can you advice people to visit for } \\
\text { relaxation? }\end{array}$} & Yes & 86 & 47.7 \\
\hline & No & 78 & 43.3 \\
\hline \multirow{6}{*}{$\begin{array}{l}\text { If the environment look good for } \\
\text { relaxation } \\
\text { Identified major attraction in the } \\
\text { destination }\end{array}$} & Yes & 70 & 38.8 \\
\hline & Trees canopies & 105 & 58.3 \\
\hline & Research site & 1 & 0.5 \\
\hline & Topography of site & 59 & 32.7 \\
\hline & Cool breeze & 4 & 2.2 \\
\hline & No answer & 11 & 6.1 \\
\hline
\end{tabular}

Table 7: Some Dominant Species of plant in the Ravine

\begin{tabular}{ll}
\hline Scientific name & Common Name \\
\hline Musanga cecropioides & Umbrella tree \\
Elaeis guineensis & Oil palm tree \\
Melicia excelsa & Iroko tree \\
Bambusa vulgaris & Indian bamboo \\
Cassia seamea & Cassia \\
Bacteria nigritana & Ant tree \\
\hline
\end{tabular}

Table 8: Some Dominant Species of plant in the Forestry Arboretum

\begin{tabular}{ll}
\hline Botanical name & Common Name \\
Nauclina arborea & Gmelina \\
Cassia seamea & Opepe \\
Acacia auriculformis & Cassia \\
Dactyladenia barterii & Acacia \\
Mammea africana & - \\
\hline
\end{tabular}

\section{Discussion}

\section{Awareness of Ecodestinations}

Awareness of the ecodestinations by most respondents irrespective of gender implies that both the Ravine and the Arboretum are unique sites within the University of Uyo community. The uniqueness of the sites could be based on the fact that they are the most vegetated parts of the University of Uyo environment that have resemblance of a natural tropical rainforest ecosystem demarcated into strata, and would therefore always draw the attention of respondents or arouse some curiosities in the mind of respondents. The teak (Tectona grandis) plantation at the University of Ibadan, the rubber (Ficus elastic) plantation at the University of Port Harcourt and the forest plantation at Michael Okpara University of Agriculture, Umudike serve 
similar purpose (Personal observations) Awareness of the Aboretum and Ravine can also be attributed to the fact that events have been holding in front of the destinations. The world environment day has been celebrated twice in the forestry shade in front of the Aboretum, and social organisations do hold meetings in front of the Ravine occasionally.

Awareness of these ecodestinations corroborates the findings of Van der Wagen (2005) that event is one of the two primary strategies used by tourist destinations to attract tourists. Hallmark events such as Argungun international fishing festival in Kebbi State, Osun/Oshogbo international annual cultural festival in Osun State, and Winners chapel religious Shiloh programme in Canaanland of Ota in Ogun State have significant tourism impact and have increased the awareness level of the respective destinations among visitors. Moreso, event like the Grand pitcher festival (Maha Kumbh Mela) of 2001, where approximately 70 million Hindu pilgrims converged on the Holy River Ganges for a sacred bathing has really increased peoples' recognition or consciousness of the destination and region as host to the largest religious gathering in history (Van der Wagen, 2005).The Maha Kumbh Mela of 2013 was attended by an estimated number of about 120 million Hindu pilgrims (Sreeja, 2013; Memmott, 2013; Taylor, 2013; KumbhMela, 2013). Allahabad, India, a city of about 1.1 million people hosted nearly 100 times its population in pilgrims during the 55 days duration of the 2013 Maha Kumbh Mela (Taylor, 2013).

\section{Perceptions of the Ecodestinations}

Majority of the respondents (Table 3) viewed the ravine as a habitat for wildlife. This can be ascribed to the fact that respondents know that wild animals live in forests, and the ravine being a major forest inside the university environment is therefore being considered the major home for wildlife species in the environment. Greater percentage of the respondents perceived the ravine as unsafe at night owing to lack of adequate security to curb nefarious activities of hoodlums and cultists. Ijeomah (2012b) obtained similar report in Rayfield resort of Plateau State where hoodlums lurk, seize, roast and consume goats of households from the host communities. This corroborates similar findings that illicit operations such as cultivation and smoking of indian hemp in forest reserves and destinations with less human traffic are common occurrences (Ndu, 2012). Members of the Timber Traders Association in Ondo State once protested concerning the establishment of large indian hemp farms in forest reserves owned by the state (Ayobami, 2012). In 2012 Indian hemp farms were discovered and destroyed in Gambari Forest Reserve of Oyo State (Olaitan, 2012); Oke Olabede Forest Reserve (Ndu, 2012); and Oloro Arinkinki Forest Reserve of Osun State (Ndu, 2012) by the National Drug Law Enforcement Agents NDLEA officials.

Notwithstanding, the uniqueness of the ravine especially in terms of cool nature and quietness of the environment, coupled with its special virtues for recreation as evidenced in the recreational operation of the keggite group therein occassionally, only $7.7 \%$ of the respondents perceived it as a recreation centre. This can be ascribed to the fear of being insecure in the environment while recreating coupled with the fear of being called an occultist by people when seen in the environment. Most keggites including females seen inside the ravine during their meetings are either erroneously viewed as occult members or friends of occultists by most members of the university community.Though more females perceived the ravine as a place for occultists, Chi square test to determine if there was any association between gender and respondents' perception of the Ravine was not significant $(p>0.05)$. Perceptions of respondents do not always differ significantly on the basis of gender in university environment, especially among undergraduates. This is because majority of the respondents, being undergraduates are still in their developmental stages and irrespective of gender are subjected to the same teachings in the institution. Their perceptions are influenced by the lectures they receive. Nevertheless, females are more cautious with issues of security than males.

In the case of the Arboretum, majority considered it as a recreation centre. Apart from the environment that looks quite natural, cool and protected cases of attacks by occult members had neither been observed nor reported in the reserve. Respondents' perception agrees with the finding 
of Eltringham (1984) that crises (or fear of insecurity) whether real or imagined can cripple visitation to ecodestinations. This also agrees with Ijeomah and Adetoro (2008) that tourists and people recreating like receiving information assuring them of their safety as regular as newly married couple will desire to receive text messages communicating how much each is loved by the partner. Many respondents also viewed the Arboretum as a site for research and practical because they have in many cases observed students working in the ecodestination and sometimes reading. Ideally, they expected that an environment for research should be noiseless, isolated and cool to allow researchers concentrate on their researches, reason critically and constructively on issues that concern their studies.This differs from the case of the ravine where anybody seen inside the destination is suspected to be an occultist. Though more female respondents perceived the Arboretum as a wildlife habitat, Chi square test of association between respondents gender and perception concerning the Arboretum was not significant ( $>$ >0.05).

\section{Willingness to Visit the Ecodestinations}

Many of the respondents have visited the ravine. Most of them visited to know how the environment looks (Table 5). These visitations may be to ascertain what the respondents may have heard about the ravine, or to know the nature of the environment that makes it a choice place for illicit meetings especially in the night. These visitations could have been done when the opportunity arose. The fact that there was no water in the University of Uyo on the day of students' matriculation of 1995 made most students to enter inside the ravine to harness water from the stream therein (inside the valley) for bathe. Notwithstanding the popularity of the ravine coupled with the recreational potentials, most respondents are unwilling to visit the ravine and will not encourage relations to enter the site for recreation because of the perception of the public about the ravine.

In the case of the Arboretum, respondents have been visiting majorly for academic purposes (study, Practical, planting of trees, seed collection) though very few still visit the site to either urinate or smoke cigarette (Table 6). Notwithstanding the fact that many respondents have not been visiting the Arboretum for recreation; they can encourage relations to enter the destination for relaxation and are willing to visit. This could be because of the wide publicity given to the destination by the mass media during the world environment day celebration.

\section{Factors that can enhance People's Visitation to the Destination}

Tree canopies were identified as the major attractions in the two ecodestinations. These trees have closed canopies and created various micro climatic conditions and micro habitats. These canopies make the environment look quite shaded and cool even when the temperature of the university environment appears to be relatively quite high. It is because of these attractive conditions that made many photographers established studios along the entrance of the Ravine close to the Music department. It was the same condition made food vendors established restaurants along the entrance of the Ravine before the university authority relocated them. Relaxing within that environment could be compared with when one is enjoying sea breeze. The valley inside the Ravine culminates in a stream, which makes the setting looks quite natural. However, the canopies are natural without any enhancement and can therefore not enable tourists have a panoramic view of the campus. The Kakum canopy walkway of Kakum national park in Ghana is suspended above tree canopy in the forest to aid tourists have a panoramic view of the biodiversity resources of the large conserved area (Lindsay, 2013).The fact that calls by birds are the commonest sounds heard in the environment makes the destinations look quite natural. The introduction of apiary in the Arboretum ecodestination makes it more natural and protected. Bees as instrument of biological warfare, apart from making the destination look natural also contributes towards protection of the environment. Introduction of games in the ecodestinations will attract tourists.

\section{Some Dominant Species in the Ecodestinations}

The dominant species in the Ravine ecodestination include Musanga cecropioides, Elaeis guineensis, Milicia excelsa, Cassia seamia, Bambusa vulgaris and Bacteria nigritana (Table 7).These species stabilize the soil, and prevent flooding in the Ravine. Milicia excelsa specifically serve as windbreak in the 
environment. The dominant species in the arboretum ecodestination are Gmelina arborea, Dactyladenia barterii, Cassia seamia, Acacia auriculformis, Nauclea diderichii, Mammae africana and Entandrophragma cylinderica (Table 8). Acacia auriculformis, Cassia seamia and Dactyladenia barterii are agroforestry species; apart from contributing in stabilizing the soil fixes nitrogen in the soil. All the species contribute in providing shade to the environment. Nauclea diderichii serves as a good species for electricity poles as it grows straight and tends to be among emergent layer of the canopy. The arboretum showcases many tree species especially the indigenous ones. The Irvingia species in the valley in the innermost part of the arboretum is very conspicuous and easily draws the attention of visitors who trail down the corridors. A section of the arboretum is planted with rows of only Gmelina arborea and Tectona grandis which are fast growing exotic species. Tamarindus indicus in the aboratum generates a lot of shade due to it very large size and canopy.

\section{Conclusion}

Both the Ravine and the Arboretum are well known sites in the University of Uyo environment. They have attractive virtues that can be harnessed for tourism development. However, none of the sites is actually managed as a recreation destination. The Arboretum has good image than the Ravine and is more valued as a recreation centre by many respondents. The ravine is mostly perceived as a wildlife habit and has a bad image which could discourage visitation if not corrected.

\section{Recommendation}

The Ravine and the Arboretum should be managed with the consciousness of attracting visitors. The two ecodestinations should be properly monitored to prevent people from using the environment for refuse disposal, smoking of Indian hemp, and as a place for defeacation. Awareness should be created to change the negative image of the Ravine in the minds of members of the University of Uyo community and outsiders. Recreational facilities should also be introduced inside the Ravine. A corridor of about three metres should be created around the Arboretum to make it look like a safari, and to enable visitors view the resources of the park with ease and to easily spot encroachment. Games should be introduced into the two destinations. There should be regulation of visitors entering the ecodestinations. Nature trails should be created inside the Ravine to enable visitors move around and interact with nature. Construction of a hanging bridge in the ravine will make the destination more enjoyable for recreating visitors, and enables visitors have a panoramic view of the destination. At least an individual each of the existing dominant tree species should be labelled with common names, scientific names and local names to educate visitors. The history of the ecodestinations should be made available for potential visitors. Some species of fish should be introduced inside the stream in the Ravine.

\section{References}

Ayobami, A. (2012). Timber traders protest closure of forest reserves in Ondo State. Premium Times. http://premiumtimesng.com/regional/11089 9-timber-traders-protest-closure-of-forestreserves-in-ondo.html. Accessed 21st August, 2013

Blangy, S. and Wood, M.E. (1993). Developing and implementing ecotourism guidelines for wildlands and neighboring communities. In: Ecotourism: A Guide for Planners and Managers (Lindberg K, Hawkins DE,eds). The Ecotourism Society, Bennington V.T.

Ceballos-Lascurain, H. (1996). Tourism, ecotourism and protected areas: the state of nature based tourism around the world and guidelines for its development. IUCN, Gland and Cambridge

Ceballos-Lascurain, H. (1987). The future of ecotourism. Mexico Journal January, 1314.

Drum and Moore. (2002). Ecotourism Development: a manual for conservation planners and managers the nature conservation. Arlington. Virginia U. S. A.

Eltringham, S. K. (1984). Wildlife Rresources and Economic Development. John Wiley and Sons Limited, New York, 324 pp.

Hetzer, W. (1965). Environment, tourism and culture. Links (July), 1-3 
Ijeomah, H.M., Alarape, A.A., Imran, T.A. (2005). Quantification of Ecotourism Resources: A case study of Jos Wildlife Park, Plateau State. Journal of Forestry Research and Management 3:87-97.

Ijeomah, H.M. (2007). Impact of Tourism on perceived poverty alleviation in Plateau state, Nigeria, Ph.D Thesis.University of Ibadan, Ibadan, Nigeria. 301pp.

Ijeomah, H.M., Dagba, B.I., Aju, P.C. (2007). Local Conservation Practices and Perception of Urashi Waterfall Ecotourism Development Project, in Dikenafai Community, Imo State. Journal of Research in Tourism1:125-141

Ijeomah, H.M., Adetoro, A.O. (2008). Tourism and Terrorism in Plateau State, Nigeria. Obeche 26:6-12.

Ijeomah, H.M., Aiyeloja, A.A. (2010). Ecotourism: An instrument for combating Renewable natural resources Degradation In: Practical Issues in Forest and Wildlife Resources Management (Ijeomah HM Aiyeloja AA eds), Green Canopy Consultants, Port Harcourt, Rivers State, pp $441-470$

Ijeomah, H.M., Alarape, A.A., Ogogo, A.U.( 2011a). Ecotourism Potentials of Plateau State, Nigeria: A Monitoring survey. Asia Pacific Journal of Tourism Research16:153 $-167$

Ijeomah, H.M., Omokhua, G.E., Ogbara, D. (2011b).Implications of Fish Blasting on Biodiversity of the Niger Delta Region in Nigeria. In: PoPoola, L., Ogunsanwo, K., Idumah, F. (eds.) Forestry in the Context of the Millenium Development Goals.Proceedings of the $34^{\text {th }}$ Annual Conference of the Forestry Association of Nigeria held in Osogbo, 05 - 10 December, 2011, pp 515 - 526

Ijeomah, H.M., Eniang, E.A., Ikiba, B.A. (2011c). Impact of the Indigenous Conservation of Sclater's guenon (Cercopithecus sclateri, Pocock) in Lagwa Community, Nigeria Journal of Agriculture, Food and Social Sciences 9: $32-38$

Ijeomah, H.M. (2012a). Challenges of Game Reserves in Nigeria: A Case Study of Pai River Wildlife Park of Plateau State. In:
Ijeomah, HM, Aiyeloja, A.A (eds) Challenges to sustainable productions in Agriculture and the Environment: Nigeria in Perspective. Topbase Nigeria limited, Lagos in conjunction with Green Canopy consultants, Port Harcourt, Rivers State.

Ijeomah, H.M. (2012b). Impact of tourism on livelihood of communities adjoining ecodestinations in Plateau State, Nigeria. Journal of Culture (Revista de Cultura e Turismo) 6:55 $\quad-71$. www.uesc.br/revistas/culturaeturismo.

Ijeomah, H.M., Herbert, B.C. (2012). Reality of Tourism Management: Business Viability and Tourists' Behaviour in Plateau State, Nigeria. Journal of Culture (Cultur Revista de Cultura e Turismo) 6:18-35 www.uesc.br/revistas/culturaeturismo.

Kotler, P., John, J.J. and Makens, J.C. (2010). Marketing for Hospitality and Tourism,fifth edition, Pearson Education Inc. Upper saddle River, New Jersey, 07458

KumbhMela (2013). Welcome to KumbhMela 2013.

http://kumbhmelaallahabad.gov.in/english/index. html, Accessed 15th August, 2013

Lindsay, H.E. (2003). Ecotourism: the promise and perils of Environmentally - oriented travel.

http://www.csa.com/discoveryguides/ecotour/ove rview.phphttp://www.bbc.co.uk/cbbc/bluep eter/world/ghana gallery3.html, Accessed 6th June, 2013

Memmott, M. (2013). Biggest gathering on earth' begins in India; kumbhmela may draw 100 million.http://www.npr.org/blogs/thetwoway/2013/01/14/169313222/biggestgathering-on-earth-begins-in-india-kumbhmela-may-draw-100-million, Accessed 15th August, 2013

$\mathrm{Ndu}$, A. (2012). NDLEA arrests palm wine tapper, wife over Indian hemp farm in Oshogbo.

Premium

Times. .http://premiumtimesng.com/news/100502ndlea-arrests-palm-wine-tapper-wife-overindian-hemp-farm-in-osogbo.html Accessed 21st August, 2013

Olaitan, K. (2012). NDLEA Destroys Indian hemp farms in Ibadan. National Mirror http://nationalmirroronline.net/new/destroy 
s-indian-hemp-farms-in-ibadan// Accessed 21st August, 2013

Sreeja, V.N. (2013). MahaKumbhMela 2013: Scores of Pilgrims Go Missing; 'Lost And Found' Centers Flooded With Requests To Locate Missing Devotees, http://www.ibtimes.com/maha-kumbhmela-2013-scores-pilgrims-go-missinglost-found-centers-flooded-requests-locatemissing, Accessed 15th August, 2013

Taylor, A. (2013). KumbhMela: The Largest Gathering on Earth. The Atlantic, http://www.theatlantic.com/infocus/2013/01/kum bh-mela-the-largest-gathering-on earth/100438/) Accessed 15th August, 2013 USAID (2005). USAID and Sustainable Tourism, Meeting Development Objectives, USAID, Washington, 102pp., www.usaid.gov Vander Wagen, L. (2005). Event Management for tourism, cultural, business and sporting events, Pearson Education Inc., Australia, P.6 